\title{
Novel electrolyte membranes and non-Pt catalysts for low temperature fuel cells
}

\author{
Simon D. Poynton*, Jamie P. Kizewski, Robert C.T. Slade and John R. Varcoe \\ University of Surrey, Chemical Sciences (C4), Guildford, Surrey GU2 7XH, United Kingdom
}

\begin{abstract}
Varying thicknesses of ethylene-co-tetrafluoroethylene (ETFE) Alkaline Anion Exchange Membranes (AAEMs) with quaternary ammonium functional groups were prepared using Ebeam irradiation. The performances in $\mathrm{H}_{2} / \mathrm{O}_{2}$ single cell fuel cells were tested at $50^{\circ} \mathrm{C}$ with the thinnest AAEM (S20) achieving the highest peak power density of $230 \mathrm{~mW} \mathrm{~cm}{ }^{-2}$. The ability to use non-Pt electrocatalysts for the oxygen reduction reaction (ORR) at the cathode was also investigated.
\end{abstract}

Key Words: Alkaline Anion Exchange Membrane; Fuel cell; Pt-free catalyst.

* Corresponding Author

Simon Poynton

University of Surrey, Chemical Sciences (C4)

Guildford, United Kingdom, GU2 7XH

Email address: s.poynton@surrey.ac.uk (Simon. D. Poynton)

Tel: $+44(0) 1483682616$ 


\section{Introduction}

Proton exchange membrane fuel cells (PEMFCs) using commercial membranes such as Nafion ${ }^{\circledR}$ from DuPont (USA) have received a large amount of focus as alternative energy supplies. However, these fuel cells often require the use of expensive Pt catalysts at the electrodes. Cheaper and more abundant non-Pt catalysts such as Au and Ag cannot be used as they are chemically unstable under the low $\mathrm{pH}$ of a PEMFC $[1,2]$. On top of the expense of using Pt based catalysts with PEMFCs, the membrane itself is also an expensive component [3].

One solution to overcome these problems would be to use an alkaline anion exchange membrane (AAEM) instead of the PEM. In this system, the membrane conducts $\mathrm{OH}^{-}$anions from the cathode to the anode rather than protons $\left(\mathrm{H}^{+}\right)$in the reverse direction. AAEMs have been successfully prepared within our lab from preformed polymer films of varying thicknesses. Due to the high $\mathrm{pH}$ of the AAEM system, cheaper, more abundant non-Pt metals such as $\mathrm{Au}$ or $\mathrm{Ag}$ can now be incorporated for the oxygen reduction reaction [4-6].

The use of AAEMs as a viable alternative to PEMs means that vast areas of research over the various components of the membrane electrode assembly (MEA) need to be revisited. Recent gas diffusion layer (GDL) optimisation within our lab discovered that there was a marked improvement in peak power density when changing the GDL of the cathode from carbon cloth to carbon paper [7]. We have also recently identified that AAEMs containing quaternary ammonium functional groups do not suffer with degradation via a carbonation effect from $\mathrm{CO}_{2}$ in either air or when supplied with a fuel such as methanol/ethanol [8] contrary to popular belief.

This study comprises of an investigation into the effect of thickness of in-house ETFE based quaternary ammonium $\mathrm{AAEMs}$ followed by performance of unoptimised $\mathrm{Au} / \mathrm{C}$ and $\mathrm{Ag} / \mathrm{C}$ cathode catalysts (made from commercially available catalyst powder) with low loading ( 0.5 $\left.\mathrm{mg}_{\mathrm{metal}} \mathrm{cm}^{-2}\right)$. 


\section{Experimental}

\subsection{Materials}

Ethylene-co-tetrafluoroethylene (ETFE) film was supplied by Nowofol Kunststoffprodukte (Germany) in 12 and $50 \mu \mathrm{m}$ thicknesses and by Goodfellow (UK) at $25 \mu \mathrm{m}$. Vinylbenzyl chloride (VBC) was supplied by Dow Chemicals and stored in the freezer at $-38 \pm 2{ }^{\circ} \mathrm{C}$ until required and used undiluted. Aqueous trimethylamine (TMA Acros Organics, 50\% also used as supplied. Aqueous potassium hydroxide (KOH, Fisher Scientific, $1.0 \mathrm{~mol} \mathrm{dm}^{-3}$ ) was used for anion conversion and $\mathrm{KOH}$ standard from Riedal-de Haën, (0.1000 $\pm 0.0001 \mathrm{~mol}$ $\left.\mathrm{dm}^{-3}\right)$ and hydrochloric acid ( $\mathrm{HCl}$, Aldrich, $0.0990 \pm 0.0001 \mathrm{~mol} \mathrm{dm}^{-3}$ ) was used for titrations.

\subsection{Preparation of the AAEMs}

The Alkaline Anion Exchange Membranes (AAEMs) were produced using 12, 25 and $50 \mu \mathrm{m}$ ETFE polymer films and were irradiated with electron-beam (Isotron, Harwell, UK) to a total dose of 4, 4 and $7 \mathrm{MRad}$, respectively. Lower irradiation levels for the thinner membranes were used as previous irradiation of $25 \mu \mathrm{m}$ ETFE with $7 \mathrm{MRad}$, caused significant mechanical degradation. The membranes were functionalised as previously reported by Varcoe et al, [9] using vinylbenzyl chloride and trimethylamine. The quaternary ammonium functionalised AAEMs were produced in the chloride form and converted into the hydroxide form by submerging in aqueous potassium hydroxide $\left(\mathrm{KOH}, 1 \mathrm{~mol} \mathrm{dm}{ }^{-3}\right.$ ) for $1 \mathrm{~h}$, changing the $\mathrm{KOH}_{(\mathrm{aq})}$ solution twice to ensure complete ion exchange before being used. All excess $\mathrm{KOH}$ was removed by washing the converted AAEMs in water (grade II water was used in all experiments).

\subsection{Electrodes}

To allow for direct analysis of the influence of the AAEM thickness, prefabricated carbon paper electrodes were used for the anodes and cathodes; these comprised of Toray carbon paper with geometric catalyst loadings of $0.5 \mathrm{mg} \mathrm{cm}^{-2} \mathrm{Pt}(\mathrm{Pt} / \mathrm{C} 20 \%$ mass catalyst particles on carbon) and an undisclosed proprietary loading of PTFE binder from E-Tek (a division of BASF). The electrodes were sprayed with $0.50 \pm 0.05 \mathrm{mg} \mathrm{cm}^{-2}$ poly(vinylbenzyl chloride) (PVBC) using ethyl acetate as a solvent and then submerged in $N, N, N^{\prime}, N^{\prime}$-tetramethylhexane- 
1,6-diamine (TMHDA, undiluted - toxic), for $24 \mathrm{~h}$ and washed with water before being ionexchange with $\mathrm{KOH}_{(\mathrm{aq})}$ (as with the AAEMs).

Tests for alternative cathode catalysts were performed using prefabricated anode electrodes containing a Type-A carbon cloth gas diffusion layer (also from E-Tek) and not carbon paper. The alternative cathode catalyst electrodes were fabricated in-house using TGPH-90 carbon paper (Toray, E-Tek) as the gas diffusion layer. Catalyst inks consisting of $0.5 \pm 0.05 \mathrm{mg} \mathrm{cm}^{-2}$ $\mathrm{Pt}, \mathrm{Au}$ or $\mathrm{Ag}$ (20\% $\%_{\text {mass }}$ metal catalyst on Vulcan XC-72 carbon support) with $0.75 \pm 0.03 \mathrm{mg}$

$\mathrm{cm}^{-2}$ PVBC in ethyl acetate were stirred for several hours before being applied to the carbon paper. After drying in air, the electrodes were submerged in TMHDA for $24 \mathrm{~h}$, washed with water and treated with $\mathrm{KOH}_{(\mathrm{aq})}$ same as the prefabricated electrodes.

\subsection{Membrane characterisation}

The thicknesses of both the hydrated and dehydrated AAEMs were measured using an external micrometer (precision $\pm 2 \mu \mathrm{m})$.

The ion exchange capacities (IEC) of the AAEMs are determined using a back titration method as described in [10]. The $\mathrm{OH}^{-}$-form AAEMs were submerged in hydrochloric acid standard for $24 \mathrm{~h}$. The solution was then titrated with potassium hydroxide standard. The AAEMs were then converted back into the hydroxide form and placed in a desiccator $\mathrm{RH}=$ $0 \%\left(\right.$ over $\mathrm{CaCl}_{2}$ ) for $7 \mathrm{~d}$ before being weighed. The IEC was calculated by (1):

$I E C=\frac{n_{i}\left(H^{+}\right)-n_{f}\left(H^{+}\right)}{m_{d r y}\left(O H^{-}\right)}$

Where $n_{i}\left(\mathrm{H}^{+}\right)$is the initial number of protons in solution, $n_{f}\left(\mathrm{H}^{+}\right)$is the final number of protons available and $m_{d r y}\left(\mathrm{OH}^{-}\right)$is the final weight of the membrane in its hydroxide form.

\subsection{Fuel cell tests}

The fuel cell tests were carried out using an Arbin Instruments (College Station, TX) Fuel Cell Test Station (FCTS). Membrane electrode assemblies (MEAs), $25 \mathrm{~cm}^{2}$ were produced without hot pressing, as the MEA has previously been proven to not laminate consistently 
once treated with poly(VBC) and TMHDA [9]. The MEA was secured between two graphite blocks which had machined triple serpentine flow channels $(1 \mathrm{~mm}$ channel width, $1 \mathrm{~mm}$ channel height and $1.5 \mathrm{~mm}$ rib width) and gold coated copper current collector plates. The fixture was sealed at a constant torque of $5.5 \mathrm{~N} \mathrm{~m}$, using bolts and a torque wrench. All testing was carried out with a fuel cell temperature of $50 \pm 1{ }^{\circ} \mathrm{C}$ with $\mathrm{H}_{2}$ and $\mathrm{O}_{2}$ at $100 \%$ relative humidity $(\mathrm{RH})$ and a flow rate of $2 \mathrm{dm}^{3} \mathrm{~min}^{-1}$.

The voltage $\left(V_{\text {cell }}, \mathrm{V}\right)$ and power density $\left(P_{\text {cell }}, \mathrm{mW} \mathrm{cm}^{-2}\right)$ against current density $\left(i, \mathrm{~mA} \mathrm{~cm}^{-2}\right)$ polarisation curves were ran in a forward scan (while going from low to high current density) before being measured in the reverse scan (high to low current density) using the built-in electronic load of the FCTS under galvanostatic control. The results were taken from the reverse scan due to a higher and more stable performance being observed when returning from high $i$ which is believed to be due to an improved conditioning of the cell. The $\mathrm{V}_{\text {cell }}$ was allowed to stabilise for between $5-10$ minutes before each data point was recorded. The voltage recorded by the FCTS was regularly verified by checking against that recorded by a calibrated battery tester (Solartron 1480). Before testing, the cell was allowed to 'condition' at high current density (potentiostatic cell discharge at $\mathrm{V}_{\text {cell }}=50 \mathrm{mV}$ ) until the current density had stabilised, this usually took between 2-3 h. This step was determined to be of high importance, as it allowed the MEA to become fully hydrated and ensured the ions and associated water were well distributed (when this step was ran for less than $2 \mathrm{~h}$, the observed peak power density was reduced). Electrochemical impedance spectroscopy (EIS) was used for identification of contributors towards voltage loss of the cell [11]; a Solartron 1260 frequency analyser connected to a 1287 electrochemical interface was attached using a two electrode connection to the running fuel cell (floating, to avoid ground loop interferences), to measure the total internal area resistance of the MEA $\left(\mathrm{r} / \Omega \mathrm{cm}^{2}\right)$ at each current density. The galvanostatically controlled dc currents were pertubated with small amplitude alternating currents at decreasing frequencies in the range of $1 \mathrm{MHz}-100 \mathrm{mHz}$ at 7 points decade $\mathrm{e}^{-1}$; the resulting ac voltage responses were recorded and the ac impedance calculated at each frequency. The amplitude of the ac current was controlled at the lowest values required for noise free spectra to be obtained. The high frequency $\mathrm{x}$-axis intercept corresponded to the cell internal resistance. 


\section{Results}

\subsection{Membrane Characteristics}

The production of the three membranes using e-beam irradiation led to evenly grafted AAEMs, characterised by the hydrated/dehydrated thickness and IEC measurements taken from multiple areas of the membranes. The average results are given in Table 1. The membranes varied in thickness according to the thickness of the original polymer film. Final hydrated thickness of 17, 46 and $85 \mu \mathrm{m}$ were achieved respectively (designated S20, S50 and S80).

There was a considerable difference in the IECs with $\mathrm{S} 20>\mathrm{S} 80 \geq \mathrm{S} 50(2.25,1.25$ and 1.15 $\mathrm{mmol}\left(\mathrm{OH}^{-}\right) \mathrm{g}^{-1}$ dry membrane respectively). It is generally agreed that there is an optimum IEC value of around $0.9-1.4 \mathrm{mmol} \mathrm{g}^{-1}$ where too high an IEC would lead to degradation of the membrane structure and too low would produce poor conductivity. However, the much higher IEC of the S20 AAEM failed to create significant structural instability and so was not deemed excessive.

Table 1

\begin{tabular}{l|l|l|l} 
AAEM & $\begin{array}{l}\text { IEC } \\
/ \mathrm{mmol}\left(\mathrm{OH}^{-}\right) \mathrm{g}^{-1} \text { (dry membrane) }\end{array}$ & $\begin{array}{l}\text { Thickness } \\
\text { Hydrated } \\
/ \mu \mathrm{m}\end{array}$ & $\begin{array}{l}\text { Thickness } \\
\text { Dry } \\
/ \mu \mathrm{m}\end{array}$ \\
\hline S80 & $1.25 \pm 0.11$ & $85 \pm 4$ & $71 \pm 2$ \\
\hline S50 & $1.15 \pm 0.10$ & $46 \pm 4$ & $38 \pm 3$ \\
\hline S20 & $2.25 \pm 0.13$ & $17 \pm 1$ & $15 \pm 1$
\end{tabular}

\subsection{Fuel cell tests: AAEMs}

The $\mathrm{H}_{2} / \mathrm{O}_{2}$ fuel cell performance of the three home-made AAEMs is presented in Figure 1, where prefabricated carbon paper electrodes were used on both the anode and cathode. There was a significant increase in performance as the thickness of the membranes was decreased, with a peak power density of $230 \mathrm{~mW} \mathrm{~cm}{ }^{-2}$ observed for the $\mathrm{S} 20$ membrane at a current density of $600 \mathrm{~mA} \mathrm{~cm}^{-2}$, compared to peak power densities of 160 and $116 \mathrm{~mW} \mathrm{~cm}{ }^{-2}$ at a current densities of 400 and $180 \mathrm{~mA} \mathrm{~cm}^{-2}$ for the thicker S50 and S80 membrane respectively. This increase in power as the membrane thickness decreases is believed to be a result of the 
increase in water crossover from the anode to the cathode through the membrane. Water is now an important reactant at the cathode for the formation of $\mathrm{OH}^{-}$ions from gaseous $\mathrm{O}_{2}$. This hypothesis as to the increased performance was verified through use of impedance spectroscopy to measure the $i r$-corrected $\mathrm{V}_{\text {cell }}$, which is presented in Figure 2.

A delayed appearance of the mass transport voltage losses is seen for the S20 AAEM at higher current densities compared to the thicker S50 and S80 membranes. In proton exchange membrane (PEM) fuel cells, mass transport is related to the decrease in oxygen diffusion to the catalyst sites at the cathode, often exacerbated through the increase in flooding at the cathode from the production of water. However, the mass transport effect in AAEM fuel cells is now believed to be a result of insufficient water transported to the cathode. Therefore a key design requirement of AAEMs, using $\mathrm{H}_{2} / \mathrm{O}_{2}$, would be the use of thinner membranes. Area resistance of the three MEAs remained constant through all current densities, indicating that there was no increase in resistance of the membrane contributing to a decrease in power at the higher power densities. It must however be noted that the area resistance of the three MEAs does not follow in the expected order with the thinnest membrane possessing the lowest area resistance. This is partly due to the MEAs not being hot pressed before running in the fuel cell, as the ionomer used will not allow adequate lamination. Therefore the area resistance of the MEAs cannot be probed fully using the current design. 


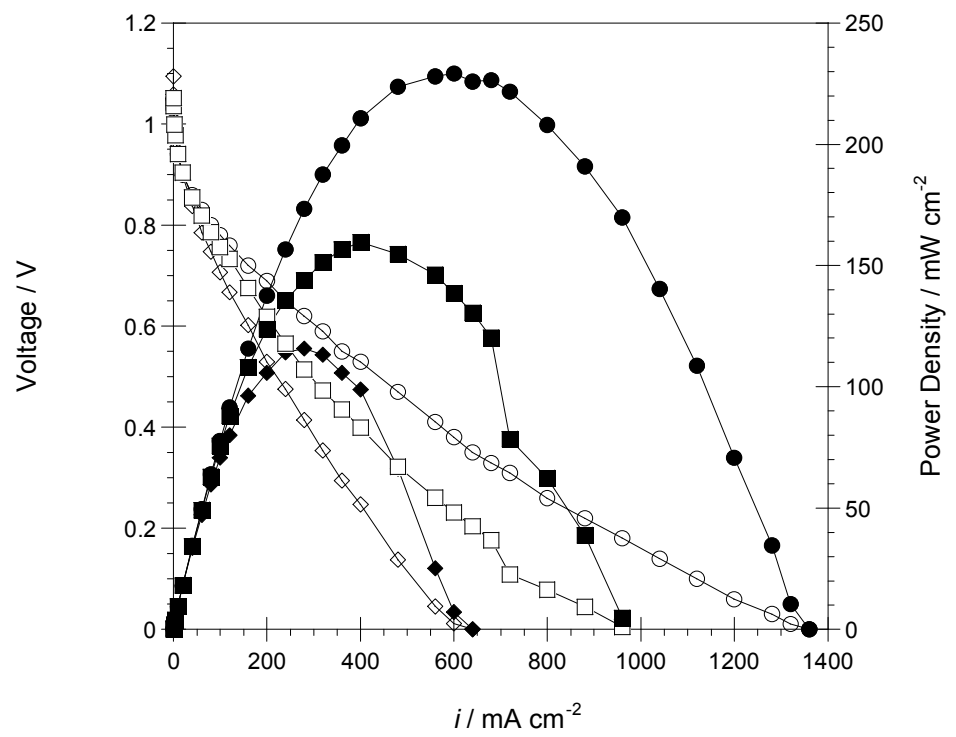

Figure 1: Fuel cell performance at $50^{\circ} \mathrm{C}$, anode: $0.5 \mathrm{mg} \mathrm{cm}^{-2} \mathrm{Pt}$ prefabricated carbon paper electrode; cathode: $0.5 \mathrm{mg} \mathrm{cm}^{-2} \mathrm{Pt}$ carbon paper electrode. With ( $\downarrow$ S 80 (AAEM, $85 \mu \mathrm{m}$ fully hydrated thickness); (-) S50 (AAEM $46 \mu \mathrm{m}$ fully hydrated thickness); (•)S20 (AAEM, $17 \mu \mathrm{m}$ fully hydrated thickness). The open symbols represent the $V_{\text {cell }}$ Vs $i$ plot and the filled symbols represent the $P_{\text {cell }}$ Vs $i$ plot.

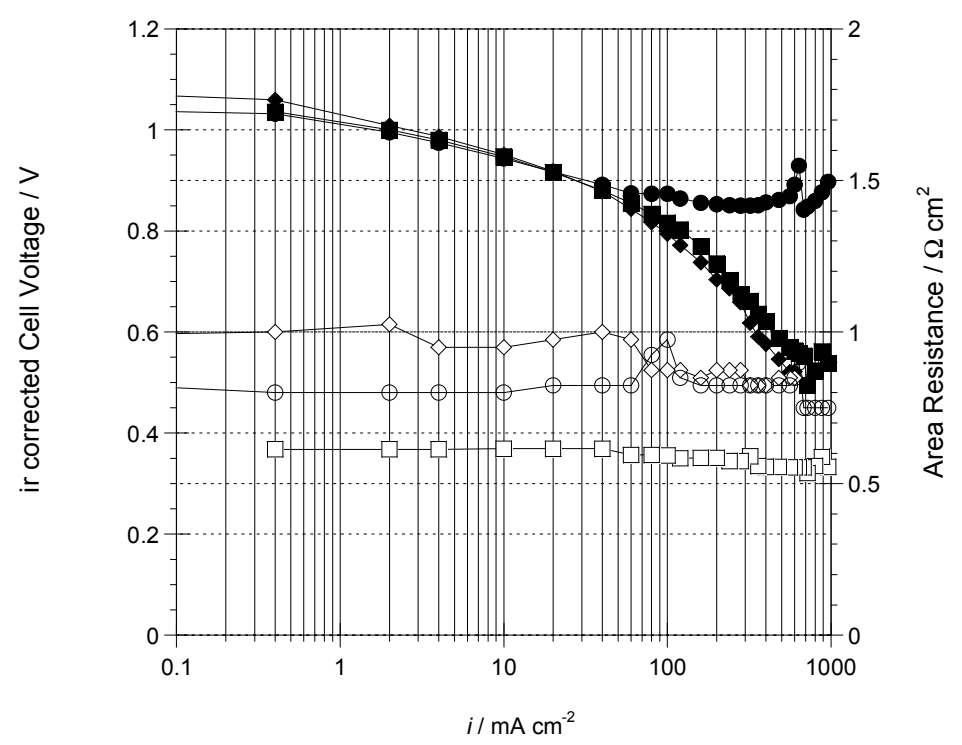

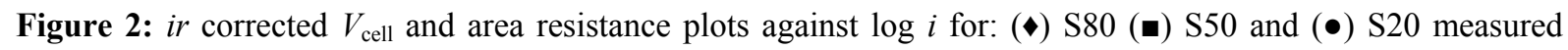
using EIS during fuel cell test with $\mathrm{H}_{2} / \mathrm{O}_{2}$ at $50^{\circ} \mathrm{C}$. Filled symbols represent ir corrected $\mathrm{V}_{\text {cell }}$ and open symbols represent area resistance data 


\subsection{Fuel cell tests: Catalysts}

$\mathrm{Pt} / \mathrm{C}, \mathrm{Au} / \mathrm{C}$ and $\mathrm{Ag} / \mathrm{C}$ were investigated for potential use as cathode catalysts within an AAEM system supplied with $\mathrm{H}_{2} / \mathrm{O}_{2}$ at $50^{\circ} \mathrm{C}$. The unoptimised cathodes were used in conjunction with prefabricated carbon cloth Pt/C anodes (E-Tek) and S80 (S80 was used in preference to the better performing S20, due to more data being available for comparison at the time of testing), under the same fuel cell test conditions used for the differing membrane thicknesses. Unsurprisingly, $\mathrm{Pt} / \mathrm{C}$ outperformed the two non-Pt metals, with a peak power density of $62 \mathrm{~mW} \mathrm{~cm}^{-2}$ at a current density of $140 \mathrm{~mA} \mathrm{~cm}^{-2}$, Figure 3 . The performance of the catalysts decreased in order of $\mathrm{Pt} / \mathrm{C}>\mathrm{Au} / \mathrm{C}>\mathrm{Ag} / \mathrm{C}$. The $i r$ corrected $V_{\text {cell }}$ Figure 4 shows that the three MEAs experienced similar overpotential trends within the ohmic and mass transport regions. The electrokinetic influence however, showed substantial initial losses, especially for the Ag and Au catalysts. Area resistances of the three catalysts varied substantially and in the order expected from the power results, decreasing in the order $\mathrm{Ag}>\mathrm{Au}>\mathrm{Pt}$ suggesting that further development of the non-Pt cathode is required for higher performances.

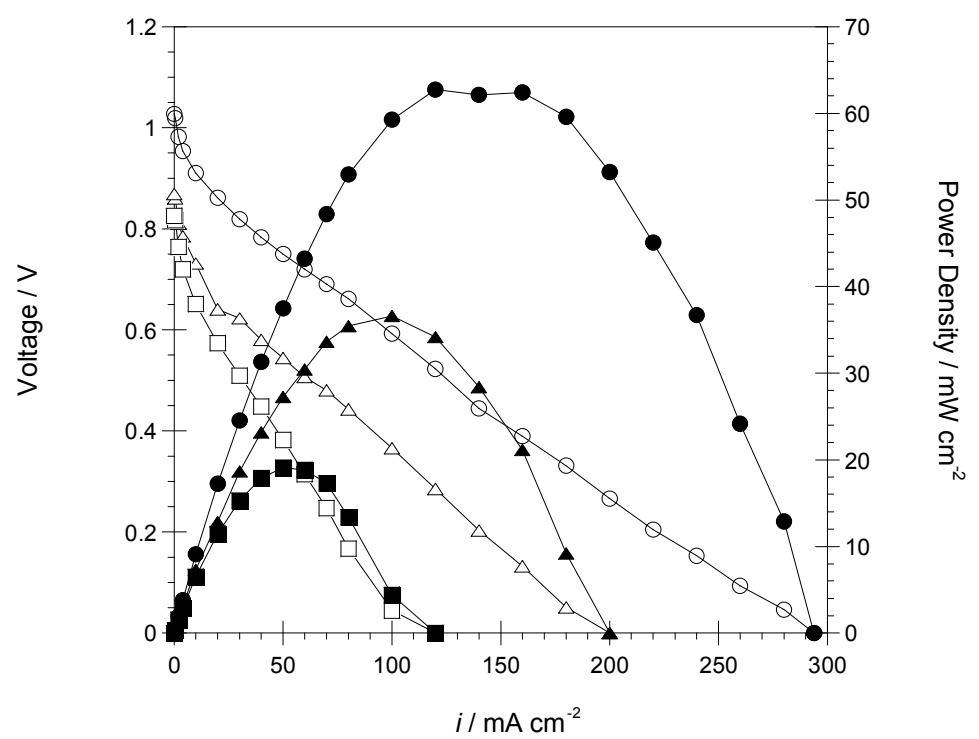

Figure 3: Fuel cell performance at $50^{\circ} \mathrm{C}$, anode: $0.5 \mathrm{mg} \mathrm{cm}^{-2} \mathrm{Pt}$ prefabricated carbon cloth electrode; cathode: $0.5 \mathrm{mg} \mathrm{cm}^{-2}$ transition metal carbon paper electrode. With $(\bullet) \mathrm{Pt} / \mathrm{C} ;(\boldsymbol{\Delta}) \mathrm{Au} / \mathrm{C}$ and $(\boldsymbol{\bullet}) \mathrm{Ag} / \mathrm{C}$. The open symbols represent the $V_{\text {cell }}$ Vs $i$ plot and the filled symbols represent the $P_{\text {cell }}$ Vs $i$ plot. 


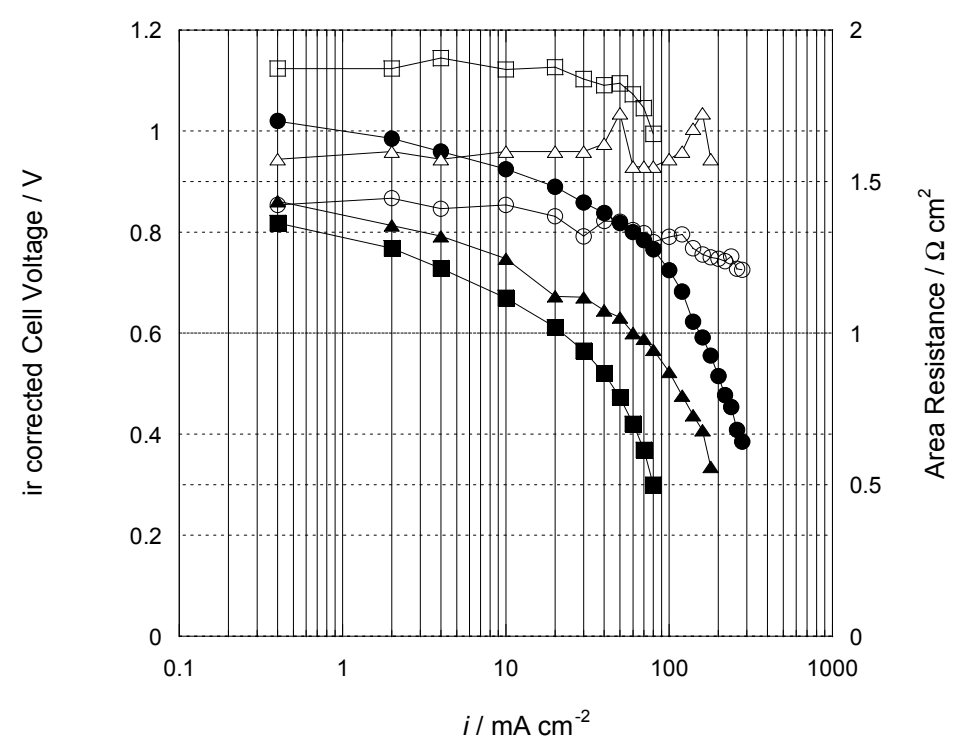

Figure 4: $i r$ corrected $V_{\text {cell }}$ and area resistance plots against $\log i$ for $(\bullet) \mathrm{Pt} / \mathrm{C} ;(\boldsymbol{\Delta}) \mathrm{Au} / \mathrm{C}$ and $(\boldsymbol{\bullet}) \mathrm{Ag} / \mathrm{C}$ measured using EIS during fuel cell test with $\mathrm{H}_{2} / \mathrm{O}_{2}$ at $50^{\circ} \mathrm{C}$. Filled symbol represents $i r$ corrected $V_{\text {cell }}$ and open symbols represent area resistance data.

\section{Conclusion}

Alkaline anion exchange membrane (AAEM) fuel cells with membrane thicknesses between $17-85 \mu \mathrm{m}$ were tested with $\mathrm{H}_{2} / \mathrm{O}_{2}$ at $50^{\circ} \mathrm{C}$. The thinnest membrane produced the maximum power density $\left(230 \mathrm{~mW} \mathrm{~cm}^{-2}\right)$ with indications that mass transport of water limited the performance of the thicker membranes.

In addition, $\mathrm{Pt} / \mathrm{C}, \mathrm{Au} / \mathrm{C}$ and $\mathrm{Ag} / \mathrm{C}$ were tested as cathode catalysts for the AAEM system. Although $\mathrm{Pt} / \mathrm{C}$ outperformed the non-Pt catalysts, the use of $\mathrm{Au}$ and $\mathrm{Ag}$ produced performances of 36 and $19 \mathrm{~mW} \mathrm{~cm}^{-2}$ respectively at the low loadings of $0.50 \mathrm{mg} \mathrm{cm}^{-2}$ (used to keep consistency across all cathodes). The performances were, however, still encouraging.

\section{Acknowledgements}

We gratefully thank the Engineering and Physical Science Research Council (EPSRC) for funding this project through a University of Surrey Doctoral Training Account. 


\section{References}

[1] M. Lefevre, J-P. Dodelet, Electrochim Acta. 48 (2003) 2749

[2] J. Larminie, A. Dicks, Fuel Cell Systems Explained. 2nd Ed. Wiley, Chichester 2003

[3] V.Neburchilov, J.Wang, H. Zhang, J. Power Sources 169 (2007) 221

[4] J. Kim, A. Gewirth, J. Phys. Chem. B 110 (2006) 2565

[5] B. Blizanac, P. Ross, N. Markovic, J. Phys chem. B 110 (2006) 4735

[6] J. Varcoe, R. Slade, G. Wright, Y. Chen, J. Phys. Chem. B. 110 (2006) 21041

[7] C. Tamain, S. Poynton, R. Slade, B. Carroll, J. Varcoe, J. Phys. Chem. C 111 (2007) 18423

[8] J. Varcoe, L. Adams, S. Poynton, C. Tamain and R. Slade. Chem. Sus. Chem., 1-2, (2008) 79

[9] J. Varcoe, R. Slade, E. Lam How Yee, S. Poynton, D. Driscoll, D. Apperley, Chem. Mater. 19, (2007) 2686

[10] R. Slade, J. Varcoe, Solid State Ionics. 176 (2005) 585

[11] V. Paganin, C. Oliveira, E. Ticianelli, T. Springer, E. Gonzalez. Electrochim Acta. 43 (1998) 3761 